\title{
IZUČAVANJE TERMINOLOGIJE U ARAPSKOM JEZIKU
}

\section{Sažetak}

Termini su neophodan alat $i$ sredstvo preciznog razumijevanja, a njihov značaj se posebno ističe na stručnim i naučnim poljima, gdje nema mjesta nedorečenosti, nepreciznosti $i$ dvosmislenosti. Uskladena $i$ integrisana terminologija još je veća pokretačka snaga koja daje moć bilo kojem jeziku da se nosi sa izazovima s kojima se danas čovječanstvo susreće. Kontinuirani razvoj terminologije je, ujedno, najvažniji preduslov za razvoj bilo kojeg jezika, a posebno najraširenijih svjetskih jezika kakav je arapski.

Ovaj rad, prije svega, pojašnjava hronološki razvoj terminologije kao nauke u arapskom jeziku, a zatim navodi najvažnije pojedince $i$ institucije koji su se u arapskom svijetu bavili ovom problematikom. Nerazdvojan dio ovoga rada jeste i rasvjetljavanje stanja na polju arabizacije naucnih oblasti, sobzirom na to da arabizacija predstavlja bitan preduvjet za praćenje svih vrsta razvoja $u$ svijetu, ali i za osavremenjivanja arapskog jezika.

Ključne riječi: terminologija, termin, mustalah, akademije za arapski jezik, arabizacija

\section{Značaj izučavanja terminologije $\mathrm{u}$ arapskom jeziku}

Arapski jezik je jedan od najbogatijih jezika po morfološkim obrascima koji mu daju veliku mogućnost obogaćivanja jezika, tvorbe novih riječi i termina, kako bi odgovorio na sve izazove koji stoje na putu njegovog razvoja.

Tvorba termina $\mathrm{u}$ arapskom jeziku je jedan od najvažnijih i najodgovornijih jezičkih i naučnih koraka u savremenom dobu, jer ispravna i prihvatljiva naučna terminologija predstavlja ugaoni kamen za

${ }^{1}$ Islamski pedagoški fakultet u Bihaću 
stvaranje savremenog arapskog naučnog jezika i predstavlja glavnu pretpostavku za arabizaciju nauka.

Arapi su kroz historiju pridavali pažnju terminologiji, odnosno terminima, što ćemo potvrditi u ovome radu i potkrijepiti relevantnim argumentima. Jedna arapska izreka, ukazujući na značaj izučavanja terminologije, kaže: Termini su ključevi svih nauka i njihovi krajnji plodovi“.2

Arapski filozof, pjesnik i islamski pravni stručnjak Ibn Hazm (994-1064) davno je isticao značaj terminologije, pa je između ostaloga rekao: " لا بد لأهل كل علم وأهل كل صنعة من ألفاظ يختصيون بها للتعبير عن مراداتهم ليختصروا بها “ - معاني كثيرة لمeophodno je da stručnjaci svake discipline i zanata imaju svoje vlastite izraze kojima će izražavati svoje namjere kako bi njima skratili mnogobrojna značenja“. 3

Ali al-Kasimi navodi izreku Al-Kalkašendija (1355-1418) koji o značaju ove teme kaže sljedeće: “معرفة المصطلح هي اللازم المحتَّم والمهمّ المقدَّم لعموم) PPoznavanje terminologije je neophodna potreba i prioritetno važna stvar, zbog sveopšte potrebe za njom“. ${ }^{4}$

U tom kontekstu, Halid Fehmi Ibrahim pojašnjavajući značaj izučavanja terminologije u arapskom jeziku je rekao: „الاهتمام بالمصطلح أيا كان مجاله المعرفي مقدمة ضرورية لأي بحث علمي وذلك أن الجميع تعارفوا فيما بينهم على أن آن “ - „Izučavanje terminologije, ma kojoj naučnoj grani pripadala, predstavlja neophodan uvod u bilo kakvo naučno istraživanje, a

\footnotetext{
${ }^{2}$ Ali al-Kasimi navodi da je to izreka Muhameda ibn Ahmeda el-Havarizmija (781-840).

${ }^{3}$ Mattad (al-), 'Abdul-'Aziz, „Al-'Usulul-'arabijje el-'islamijje li 'ilmil-mustalah“, Medželle el-'aklam es-sekafijje, http://www.aklaam.net/newaqlam/aqlam/show.php?id=10691

${ }^{4}$ Kasimijj (al-), 'Ali, 'Ilmul-istilah ve sina'atul-mustalah, Mektebe Lubnan, 2008., str. 4.
} 
to je zbog toga jer su se svi složili da terminologija predstavlja naučno oruđe“. 5

Iz svih ovih izreka i citata dâ se zaključiti da su Arapi još od davnina shvatili i uvidjeli značaj korištenja i istraživanja termina.

U zadnja dva-tri vijeka evidentna je stagnacija u arapskom jeziku, pa je, samim tim, i bavljenje terminologijom zapostavljeno. Ako se još uzme $u$ obzir činjenica da su Arapi kao nacija bili marginalizirani na polju tehnološkog napretka i da je period njihove stagnacije trajao poprilično dugo, onda je potpuno jasno da treba posvetiti veliku pažnju obezbjeđivanju resursa kako bi arapski jezik sustigao druge jezike na polju terminologije, što je preduslov za naučni i svaki drugi napredak.

Jedan od najvećih i najaktivnijih arapskih stručnjaka za terminologiju, Ali إنّ التقدّم ” " al-Kasimi je o značaju izučavanja terminologije rekao sljedeće: في المعرفة البشريّة والتكنولوجيا والاقتصاد يعتمد إلى حدّ كبير على توثيق المعلومات

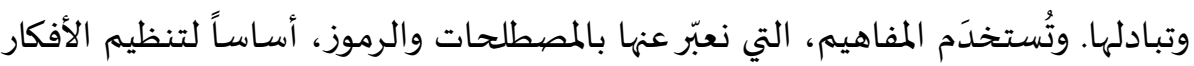

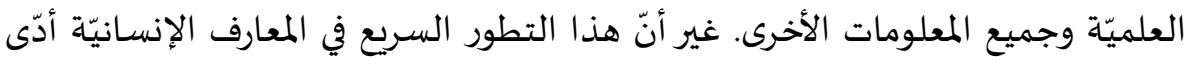

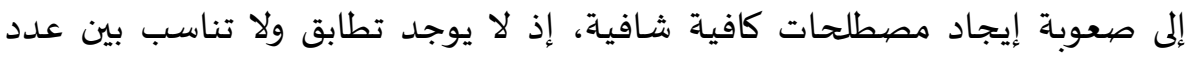

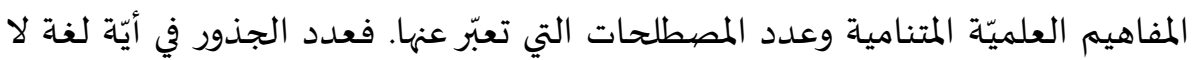
يتجاوز الآلاف على حين يبلغ عدد المفاهيم الموجودة الملايين وهي في ازدياد ونمو “ - مضطردين. Napredak na polju ljudskog znanja, tehnologije i ekonomije u velikoj mjeri se oslanja na dokumentiranje i razmjenu podataka. Pojmovi koje nazivamo terminima ili simbolima se koriste kao osnova za sistematizaciju naučnih ideja i svih ostalih podataka. Međutim, ovaj brzi razvoj ljudskog znanja doveo je do poteškoća u iznalaženju dovoljnih i adekvatnih termina, jer ne postoji podudarnost i srazmjer između broja rastućih naučnih pojmova i broja termina koji na njih ukazuju. Broj

${ }^{5}$ Ubbezijj (al-), Šihabuddin, Bejan kašfil-'elfaz, Maktaba al-Handži, 2002., str. 5. 
korijena u bilo kojem jeziku ne prelazi cifru od nekoliko hiljada, dok broj postojećih pojmova dostiže nekoliko miliona, a još su u stalnom porastu“. ${ }^{6}$

Mnoštvo je novih izazova na koje savremeni arapski lingvisti treba da daju odgovore. Tu se posebno ističe razvoj sredstava savremene komunikacije i savremenih tehnologija uopšte, kompjuterskih posebno. Sve to ima za cilj da dâ veći značaj nauci o terminima koja obogaćuje leksiku arapskog jezika.

Terminologija, koja se početkom XX vijeka pojavila kao nauka zasnovana na razrađenim pravilima i zakonima, predstavlja odgovor na naučne i socijalne izazove u cilju imenovanja novih naučnih pojmova. Pri tome, neophodno je bilo sprovesti standardizaciju koja bi uniformisala tvorbu, klasifikaciju i usvajanje termina u skladu s naučnom metodom oko koje su se složili lingvisti i stručnjaci pojedinih naučnih grana. Sve to je natjeralo čovječanstvo, a među njima i Arape, da se pozabave ovom tematikom i da pojedinačno i institucionalno idu u korak sa svim izazovima, koje ovo, relativno novo, područje naučnog zanimanja iziskuje.

Evidentno je da Arapi, zbog mnogobrojnih razloga, nisu bili u stanju da odgovore svim izazovima modernizacije života i novih otkrića na polju nauke i tehnike. Upravo zbog toga raste značaj bavljenja terminologijom u arapskom jeziku, jer će arapski jezik, ukoliko se ne bude uhvatio u koštac sa svim tim izazovima, ostati izoliran i daleko od savremenih kretanja, a stotine miliona osoba koje govore tim jezikom biće suočene sa zaostalošću ili će morati tražiti izlaz u učenju stranih jezika, poput engleskog ili francuskog, zapostavljajući pri tome svoj maternji jezik. Upravo to se desilo krajem XIX vijeka u Egiptu, gdje su u viskoobrazovnim institucijama počeli uvoditi novi termini, prevođenjem ili arabiziranjem stranih. I pored toga u visokom obrazovanju su se i dalje koristili strani jezici, što je u velikoj mjeri narušilo akademski nivo obrazovanja u arapskom svijetu.

Značaj izučavanja nauke o terminima dolazi do izražaja i zbog toga što dvoznačnost termina i njihova neujednačenost mogu dovesti do nastanka

${ }^{6}$ 'Ilmul-istilah ve sina'atul-mustalah, str. 1. 
različitih verzija arapskog naučnog jezika i do „terminološkog nesklada“ (ar. et-tedarub el-mustalahijj), kako to navodi Muhamed Ali al-Zerkan. Zbog toga, veoma je bitno da se institucionalno i sinhronizirano pristupi izučavanju, stvaranju i usvajanju termina kako bi se izbjegao eventualni terminološki nesklad. Međutim, s tim se ne slaže Džemil al-Melaike (1921-2005) koji smatra da to nije prepreka na polju ujednačavanja terminologije u arapskom jeziku. On o tome kaže sljedeće: “ إههم على أية حال يبالغون في أهمية هذا التوحيد والادعاء بأنه العقبة الكأداء في درب التعريب. فقد

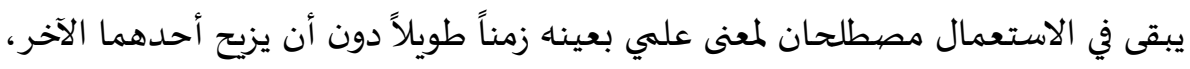

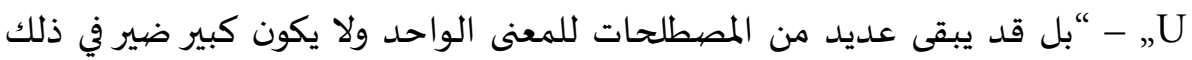
svakom slučaju, oni preuveličavaju značaj objedinjavanja i tvrdnju da ono predstavlja ozbiljnu prepreku na polju arabizacije. Ima primjera gdje dugo vremena u upotrebi ostaju dva termina koja označavaju isti naučni pojam, a da ne uspiju potisnuti jedan drugoga. Šta više, dešava se da postoji nekoliko termina za jedan pojam i da to ne predstavlja veliku štetu“.”

Uviđajući značaj terminologije, sve su češći pozivi da se ona u arapskom jeziku izučava kao predmet na svim univerzitetima, visokim školama i institutima, po uzoru na brojne svjetske univerzitete.

\section{Jezično i terminološko značenje riječi termin (ar. mustalah) u arapskom jeziku}

Riječ mustalah ${ }^{8}$, koja u arapskom jeziku označava „termin“, izvedena je iz glagola 'istalaha - „dogovoriti se“, „izmiriti se (međusobno)“, „usaglasiti

\footnotetext{
7 Sama‘ane, Dževad Husni, „Menhedžijetul-vad'i el-mustalah el-'arabijj ve tedžellijatuha fi el-mu'džem el-mutehassis“, Nedve ed-dirase al-mustalahijje ve al-'ulum al-'islamijje, Matba'a el-me'ariful-džedide, Rabat, 1996., str. 132.

${ }^{8}$ Vode se duge rasprave oko toga da li se za terminologiju koristi izraz mustalah ili 'istilah. Prvi smatraju da je riječ mustalah pogrešna iz tri razloga: a) zato što su relevantni stručnjaci i Arapi koristili samo riječ 'istilah, b) zato što nije u skladu sa pravilima arapskog jezika, i c) zato što nije moguće naći tu riječ u arapskim rječnicima. Drugi, koji odobravaju upotrebu termina mustalah na to odgovaraju da su ovaj izraz koristili učenjaci nauke metodologije hadisa, te da je u skladu sa pravilima arapskog jezika, odnosno da je ona spomenuta u rječnicima arapskog jezika, poput El-Vedžiza, rječnika Akademije za arapski
} 
se“. ${ }^{9}$ Osnova ovoga glagola ili njegov konsonantni korijen je $S L H$, a oblik 'istalaha spada u osmu proširenu vrstu glagola.

\section{Definicija riječi mustalah}

1. Naslanjajući se na jezičko značenje riječi mustalah, al-Zebidi (17321790) u svom rječniku Tadžul-arus definiše termine kao: , اتفاق طائفة مخصوصة على أمر مخصوص - , dogovor specijalne grupe ljudi o specijalnom pojmu“. ${ }^{10} \mathrm{Al}$-Zebidi je bio prvi autor jednog arapskog monolingvalnog rječnika koji je definisao ovaj izraz.

2. Sinani Sinani definiše terminologiju na sljedeći način: , لفظ معين تواضع إن إن “izraz oko kojeg se usaglasila određena grupa ljudi s ciljem skraćivanja izraza koje koriste u govoru ili poslovanju“. ${ }^{11}$

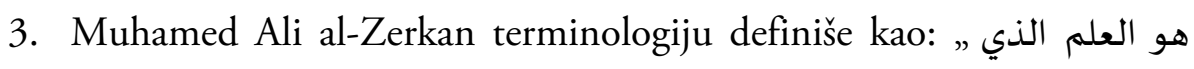
"nauku

jezik u Kairu. Razlog njenog nespominjanja u drugim rječnicima jeste činjenica da se izvedenice ne stavljaju u rječnike. Oko ovog pitanja se rasprapravljalo u nekoliko stručnih radova, na primjer u izlaganju Huseina Kinvana sa Filozofskog fakulteta Univerziteta u Maknasu u radu izloženom na simpoziju Terminološka istraživanja $i$ islamske nauke, održanom 1993. godine u Fesu (Maroko). Na kraju se može konstatovati da su svi izrazi, tj.: 'ilmul-mustalahat, al-mustalahatijje, al-mustalahijje, 'ilm al-istilah, 'ilm al-mustalahprihvatljivi, te da su svi oni sinonimi. Kinvan, el-Husejn, „Ed-Dirase el-mustalahijje mefhumen ve menhedžen", Nedve ed-dirase el-mustalahijje ve el-ulum el-islamijje, Matba'a el-me'arif el-džedide, Rabat, 1996., str. 33-41.

${ }^{9}$ Muftić, Teufik, Arapsko-bosanski rječnik, El-Kalem, Sarajevo, 2004., str. 809.

${ }^{10}$ Zebidi (al-), Murteda, Tadžul-'arus, Vizaretul-'iršad ve el-'enba', Kuvajt, 1969., str. $4 / 551$.

11 Sinani, Sinani, Al-Tetavvur ed-dilalijj li el-mustalah el-fikhijj, Medžma' el-luga el'arabijje, Damask, br. 85, tom' 3, 2010., str. 825. 
koja istražuje vezu između naučnih pojmova i jezičkih izraza koji na njih ukazuju“. ${ }^{12}$

4. Husein Kinvan smatra da je najadekvatinija definicija terminologije sljedeća: " prenošenje izraza iz jezičkog u drugo značenje zbog postojanja prikladnosti između ta dva značenja"13, jer se u tom procesu uslovljava da prenosilac bude upoznat sa karakteristikama onoga što prenosi (tj. jezika) i onoga $\mathrm{u}$ što prenosi. To podrazumijeva postojanje jasne prikladnosti između jezičkog i terminološkog značenja, pri čemu se jezičko značenje prenosi u terminološko, bez obzira da li se proširuje ili sužava. ${ }^{14}$

\section{Analiza definicija}

Iz spomenutih definicija možemo zaključiti sljedeće:

1. radi se o zasebnoj nauci koja ima svoja pravila na osnovu kojih se tvori izraz koji se koristi kao termin;

2. termin treba da bude rezultat dogovora stručnjaka određene oblasti ili opšteprihvaćen od strane stručnjaka neke oblasti $;^{15}$

3. autori definicija terminologije, u većini, su saglasni da se uslovljava postojanje sličnosti (ar. mušabehe) ili prikladnosti (ar. munasebe) između osnovnog i terminološkog značenja;

4. najznačajniju ulogu u definisanju termina ima jezik, jer se njime precizno određuje riječ koja će služiti kao termin; termin svoje osnovno

\footnotetext{
12 http://www.reefnet.gov.sy/booksproject/turath/77/7mustalah.pdf

${ }^{13}$ Nedve ed-dirase el-mustalahijje ve el-'ulum el-'islamijje, str. 45.

${ }^{14}$ Više o definicijama terminologije u arapskom jeziku vidi rad: Kinvan, el-Husejn, EdDirase el-mustalahijje mefhumen ve menhedžen, str. 42.

15 Ovaj uslov osporavaju neki autori, jer smatraju da je moguće da pojedini autori u svojim radovima ili knjigama upotrijebi neki izraz, a da tek naknadno bude općeprihvaćen od strane ostalih stručnjaka te oblasti.
} 
značenje crpi iz jezika, ali u kreiranju njegovog terminološkog značenja učestvuju i druge nauke;

5. terminološko značenje se razlikuje od osnovnog značenja;

6. svaki jezik ima svoje metode i načine bogaćenja leksikom tako da stvaranje termina treba da bude usklađeno sa normama svakog jezika ponaosob.

Iako se to ne spominje u navedenim definicijama, bitno je napomenuti da se u pojedinim naukama, kakva je hemija, terminima smatraju i simboli koji ukazuju na određene hemijske supstance.

\section{Korištenje izraza mustalah u sakralnim tekstovima islama}

Riječ mustalah - „termin“, rijetko se koristi u sakralnim tekstovima Kur'ana ili sunneta. Pored činjenice da se jako rijetko upotrebljava, potrebno je napomenuti da je korišten, isključivo, u njegovom jezičkom značenju, tj. u smislu „sporazuma“, „dogovora“, a ne u svom terminološkom značenju.

Jedan od rijetkih primjera korištenja riječi mustalah - „termin“ u sakralnim tekstovima islama jeste i hadis o sklapanju ugovora između muslimana i Kurejšija u poznatom historijskom događaju pod imenom Sporazum na Hudejbiji, gdje se navodi sljedeće: “هذا ما اصطلح عليه محمد بن عبد الله

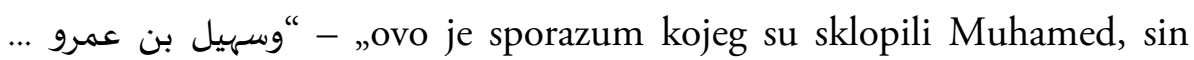
Abdulahov i Suhejl, sin Amrov...".16

Također, jedan od primjera korištenja ovog termina u značenju „dogovor“, „sporazum“ jeste i izreka Muhameda, s.a.v.s., koji je, govoreći o predznacima Sudnjega dana, između ostalog rekao i sljedeće: “ثم يصطلح

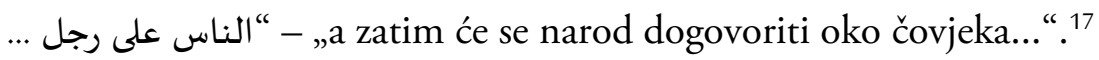

\footnotetext{
${ }^{16}$ Hadis bilježi Ahmed ibn Hanbel u Al-Musnedu (br. 18812).

${ }^{17}$ Hadis bilježi Ebu Davud u Sunenu (br. 4242).
} 


\section{Uslovi da bi neka riječ postala termin}

Da bi neka riječ stekla status termina potrebno je da ispunjava sljedeće uslove:

1. saglasnost učenjaka određene naučne oblasti;

2. postojanje razlike između terminološkog i osnovnog jezičkog značenja riječi koja stiče status termina;

3. postojanje prikladnosti ili sličnosti između osnovnog i terminološkog značenja riječi koja stječe status termina. ${ }^{18}$ To potvrđuje i Mustafa al-

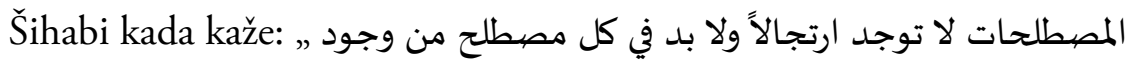
مناسبة أو مشاركة أو مشابهة كبيرة كانت أو صغيرة بين مدلوله اللغوي ومدلوله بله “ - "الاصطلاحي مerminologija ne nastaje improviziranjem, nego je neophodno za svaki termin da između njegovog jezičkog i terminološkog značenja postoji manja ili veća prikladnost, sudjelovanje ili sličnost“.

\section{Karakteristike dobrog termina}

Ukoliko želimo klasificirati termine na bolje ili lošije, ili dati smjernice za tvorbu novih termina u arapskom jeziku, onda će sljedeći uslovi služiti kao uputstva kojih se pojedinci ili institucije koje se bave tvorbom novih termina moraju pridržavati:

1. preciznost,

2. sažetost,

3. jednostavnost izraza,

4. mogućnost da se iz njega derivira drugi izraz,

5. jezička ispravnost i raširenost njegovog korištenja.

18 Ilmul-istilah ve sina'atul-mustalah, str. 4-5. 


\section{Iskustvo Arapa kroz historiju na polju bavljenja terminologijom}

Već u VIII vijeku Arapi su bili suočeni sa nadiranjem novih nauka koje su sa sobom donosile i mnoštvo novih naziva, koje je trebalo uvesti u upotrebu u arapskom svijetu, odnosno trebalo je pristupiti stvaranju novih termina $\mathrm{u}$ arapskom jeziku. To je za Arape toga perioda bio veliki izazov s kojim su se oni suočili odgovorno i u konačnici veoma uspješno.

Formiranje naučne terminologije kod Arapa veže se za nastanak samih nauka, umjetnosti i zanata, njihov razvoj i sazrijevanje.

Arapski jezik se kroz historiju u tri navrata uspješno nosio sa prilivom novih pojmova i njihovom nominacijom. Jezički stručnjaci su vrlo uspješno za njih pronalazili adekvatna terminološka rješenja čime su pokazali i dokazali sposobnost arapskog jezika da se razvija i ide u korak sa zahtjevima vremena.

Dolaskom islama pojavili su se novi vjerski, ekonomski, sociološki i naučni pojmovi za koje su naučnici pronašli adekvatne odgovore. Tom prilikom je došlo do značajnog priliva novih termina u arapski jezik, prije svega vjerskih i vjersko-pravnih. O tome Teufik Muftić (1918-1993) kaže sljedeće: „Osim istaknutog uticaja kur'anskog jezika na formiranje arapskog književnog jezika, od posebnog je značaja uopšte pojava islama i razvoj arapskog društva pod njegovim uticajem (širenje novih vidika, razvoj nauke), što je sve imalo učinka u oblikovanju samog jezika; njegove semantike, stilistike, vokabulara i drugih jezičkih karakteristika“" ${ }^{19}$

Pod uticajem razvoja omajadske države, halifa Abdulmelik ibn Mervan (vladao 685-705) je naredio da se arabiziraju registri preuzeti od Bizantinaca i Persijanaca, iako su postojali i registri na arapskom jeziku koje je prije njega uveo Omer ibn al-Hattab (579-644), čime je arapski jezik postao bogatiji za veliki broj stručnih termina iz oblasti uprave, politike i ekonomije. Upravo je isti halifa odredio arapski jezik kao zvanični jezik islamske države, što je značilo apsolutnu dominaciju

${ }^{19}$ Muftić, Teufik, Gramatika arapskog jezika, Ljiljan, Sarajevo, 1998., str. 11. 
arapskog jezika nad drugim tada upotrebljavanim jezicima, poput persijskog, grčkog, hebrejskog i drugih.

Značajan iskorak na polju bogaćenja arapskog jezika terminologijom napravljen je za vrijeme abasidske države kada je, za potrebe prevođenja grčke, indijske i persijske filozofije na arapski jezik, halifa Me'mun (786833), sin Haruna al-Rašida naredio da se osnuje Dar al-hikma u Bagdadu, što je bila prekretnica na polju procvata nauka u arapskom svijetu, a posebno na polju ustanovljavanja stručne arapske terminologije.

„Zgodno je primijetiti da je arapski jezik potvrdio elastičnost i mogućnost razvoja, sposobnošću da prihvati sve novo u razdoblju prevođenja nasljeđa susjednih zajednica. Da nije bio tako prilagodljiv, ne bi mogao odgovoriti potrebama prevodilačkog pokreta, pogotovo kad se radilo o novom nazivlju iz logike i filozofije “. ${ }^{20}$

Profesor na Univerzitetu u Kairu i član Akademije arapskog jezika u Kairu Fehmi Hidžazi smatra da je terminologija privlačila pažnju arapskih lingvista još u VIII vijeku, zbog prevođenja naučnih djela sa grčkog i drugih jezika na arapski. Naime, tada su se prevodioci susreli sa velikim brojem naučnih disciplina, a samim tim i sa mnoštvom njima do tada nepoznatih termina, pa je bilo potrebno da ih preuzmu i arabiziraju, kako bi se spomenute nauke i termini shvatili na ispravan način. ${ }^{21}$

Al-Džahiz, čuveni arapski lingvista, smatra da su se apologeti prvi počeli baviti terminologijom, te da su oni bili predvodnici svim ostalim autorima.

O tome kaže sljedeće: „وهم تخيروا تلك الألفاظ لتلك المعاني وهم اشتقوا من كلام

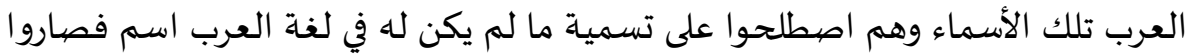
(O) - Oni su odabrali te riječi za ta značenja i iz govora Arapa izveli određene riječi, tako da su odredili nazive za pojmove koji nisu imali imena $u$ arapskom jeziku, pa su time postali

\footnotetext{
${ }^{20}$ Kico, Mehmed, Arapska jezikoslovna znanost, Sarajevo, 2003., str. 236.

${ }^{21}$ Devr al-mustalahat al-muvahhade fi ta'rib al-'ulum ve nešri al-ma'rife, Al-Lisan al'arabijj, str. 1-2.
} 
predvodnici svima koji dolaze poslije njih i uzor za one koji slijede“. ${ }^{22}$ Nakon toga je u svom drugom djelu Al-Hajavan podrobnije pojasnio kakva je priroda transformacije riječi u termine: "ترك الناس ما كان مستعملاً في الجاهلية أموراً كثيرة، فمن ذلك تسميتهم للخراج (إتاوة) وكقولهم للرشوة ولما يأخذه

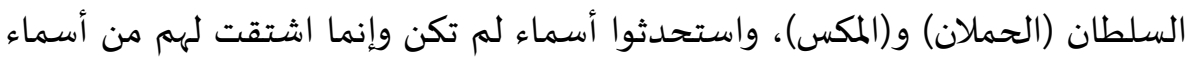

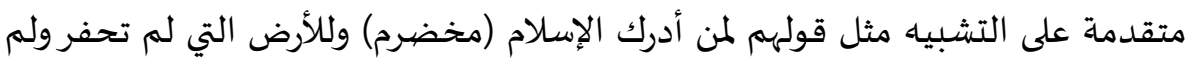

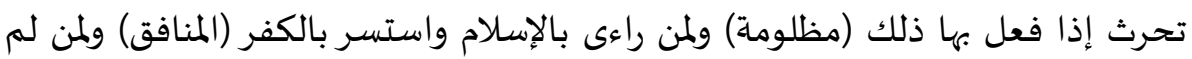
Narod je ostavio mnogo stvari koje su bile prisutne u predislamskom periodu. Jedna od njih jeste riječ itava koju su koristili za 'porez', a 'mito' i 'sve što prisvaja vlast' nazivali su al-humlan i al-meks. Izmislili su imena koja nisu postojala, tako što su derivirali nova imena iz postojećih putem poređenja, poput riječi muhadrem za 'osobu koja je živjela u predislamskom periodu i periodu nakon dolaska islama'. Također, tu su i riječi: mazlume za 'zemlju koja se obrađivala nakon dugog perioda zapostavljanja', te munafik za 'osobu se pretvarala da je vjernik, a prikrivala nevjerstvo', kao i riječ al-sarura za 'osobu koja nije obavila hadž zbog nemogućnosti ili nevjerovanja u obligatnost njegove obaveze'“ ${ }^{23}$

Kako je vrijeme prolazilo Arapi su bili svjesniji značaja sastavljanja stručnoterminoloških rječnika, s obzirom na to da su već imali iskustva na tom planu.

Među najznačajnijim djelima koja su se još od davnina bavila terminima $\mathrm{u}$ arapskom jeziku su:

1. Mefatihul-'ulum Havarizmija (780-850),

2. Mefatibul-'ulum Sekakija (1160-1229),

3. Al-Ta'rifat Džurdžanija (1339-1413),

4. Al-Kullijjat Kefevija, i

${ }^{22}$ Džahiz (al-), 'Amr, Al-Bejan ve al-tebjin, Dar al-Handži, Kairo, 1998., str. 139.

${ }^{23}$ Džahiz (al-), 'Amr, Al-Hajevan, Maktebe Mustafa al-Babi, Kairo, 1965., str. 327-347. 


\section{Kašsaf istilahat al-funun Al-Tehanevija.}

Svaki od pomenutih autora dao je značajan doprinos bavljenju terminologijom u arapskom jeziku; bitno je još napomenuti da su ovo najpoznatija djela, jer je broj onih koji su se bavili terminologijom u užem ili širem smislu veoma veliki.

Tokom perioda stagnacije (ar. 'usur al-inhitat), kada je razvoj arapskog jezika stao, desio se i očigledan zastoj na planu tvorbe novih naučnih i stručnih termina. Dominaciju u ovom periodu imali su strani termini kojima su se arapski filolozi nastojali suprotstaviti. Tokom ovoga perioda, pa sve do epohe arapskog buđenja (ar. al-nehda al-'arabijje al-hadise) došlo je do stagnacije razvoja terminologije na arapskom jeziku. ${ }^{24} \mathrm{I}$ pored svih prepreka, arapski jezik je zalaganjem pojedinaca, a kasnije i institucija, uspijevao da prati skoro sve oblike napretka u svijetu.

U XIX vijeku Arapi su se nakon dugog i dubokog sna počeli buditi i uviđati koliko su zaostali za Evropljanima, ali i koliko je arapski jezik kasnio u razvoju za drugim svjetskim jezicima, posebno kada je u pitanju terminologija. Konkretniji koraci na tom planu poduzeti su u Egiptu za vrijeme vladavine Muhameda Ali-paše (1769-1849) koji je uveo da se u školama i institutima izučavaju savremene nauke na arapskom jeziku, čime su $\mathrm{u}$ arapskom svijetu, nakon dugog mirovanja, načinjeni prvi koraci $\mathrm{u}$ oblasti stvaranja različitih terminosistema. Posebna zasluga na tom polju pripada nekolicini velikana - Rifatu al-Tahtaviju (1801-1873), Butrus alBustani, Faris al-Šidjak (1804-1887) i Mustafa al-Šihabi koji su svojim nesebičnim trudom i zalaganjem u velikoj mjeri doprinijeli ponovnom buđenju i reaktiviranju naučnog bavljenja terminologijom.

\section{Terminologija i arapski jezik danas}

Arapska naučna terminologija usko je vezana za napredak i razvoj industrije, nauke, umjetnosti i svakog drugog polja ljudskog djelovanja. Ukupna dešavanja na političkoj, društvenoj i ekonomskoj sceni u

${ }^{24}$ Zafnaki, Safijja, Al-Menahidž al-mustalahijje, Al-Hej'e al-'amme as-surijje lil-kitab, 2010., str. 88-90. 
arapskom svijetu imala su direktan uticaj na napredak/stagnaciju nauke o terminima $\mathrm{u}$ arapskom jeziku. Gubljenje samopouzdanja, kolonijalizam, autokratija, nedostatak osnovnih sloboda i loše upravljanje naučnim i svim drugim resursima uticali su negativno na Arape, uopšte, a posebno na nauku o terminima u arapskom jeziku.

Kolonijalne vlasti, koje su upravljale većinom arapskih teritorija i surovo ih eksploatisale, nisu dozvoljavale upotrebu arapskog jezika, posebno u visokom obrazovanju. Šta više, napredovanje na društvenoj ljestvici zavisilo je od priklanjanja kolonijalnim namjesnicima, njihovom jeziku i kulturi. Zbog toga je oslobađanje arapskih zemalja od kolonijalnih sila, nedvojbeno, doprinijelo da se arapski jezik razvija, a samim tim i nauka poznata kao 'ilm al-mustalah ili 'ilm al-istilah, odnosno „nauka o terminima u arapskom jeziku“. Najbolji primjer za to su zemlje arapskog Magreba gdje je arapski jezik skoro iščezao iz upotrebe u nekim sektorima društva u vrijeme francuske okupacije tih zemalja, a francuski jezik postao dominantan. Danas, usprkos zalaganjima država tog regiona i državnih institucija, te opredijeljenosti da se arapskom jeziku vrati mjesto zvaničnog jezika, jezika nauke i javnog života - tragovi jezičkog kolonijalističkog uticaja su više nego očiti i više od pola vijeka nakon oslobađanja tih zemalja.

Stručnjaci koji su pisali o razvoju nauke o terminima kod Arapa, nisu saglasni kada i koliko su se Arapi počeli baviti terminologijom u savremeno doba na moderan način, po uzoru na Zapad. Muhamed Ali al-Zerkan smatra da je obnova arapskoga jezika krenula početkom XIX vijeka, a da taj vijek predstavlja „prelazni period“ između potpunog zastoja i aktivnog bavljenja savremenim terminološkim izrazima (bilo putem arabizacije ili prevoda). On, dalje, smatra da je Prvi svjetski rat bio tačka prekretnica u bavljenju terminologijom kod Arapa, jer je tada arapski svijet zatvorio stranicu pod osmanskom upravom i počeo svoju konačnu i odlučnu antikolonijalnu bitku za nezavisnost.

Većina stručnjaka koji se bave terminologijom u arapskom jeziku smatra da se početak savremenog sistemskog bavljenja terminologijom u arapskom jeziku dogodio krajem prve četvrtine XX vijeka, tačnije leksikografskim djelom Muhameda Šerefa (1890-1949), rječnikom 
Mu'džem 'inklizi 'arabi fil-ulum et-tibbijje vet-tabi ïjje koji je izdat 1924. godine. Značaj ovog rječnika se ogleda u tome što je to prvi stručni rječnik koji sadrži opširan uvod u kojem je autor pojasnio metodologiju primijenjenu prilikom tvorbe i prevođenja novih termina.

$\mathrm{Na}$ planu unapređenja terminologije i terminoloških istraživanja $u$ arapskom svijetu, organizirano je nekoliko konferencija i simpozijuma o arabizaciji termina, a mi ih navodimo hronološkim redoslijedom.

1. I konferencija o arabizaciji termina održana je 1961. godine u Rabatu (Maroko)

2. II konferencija o arabizaciji termina održana je 1973. u Alžiru (Alžir)

3. III konferencija o arabizaciji termina održana je 1977. u Tripoliju (Libija)

4. Simpozij o arabizaciji termina održan je 1981. u Tangeru (Maroko)

5. Simpozij o arabizaciji termina održan je 1985. u Amanu (Jordan)

6. Simpozij o arabizaciji termina održan je 1986. u Tunisu (Tunis)

7. Internacionalni i arapski simpozij o terminologiji održan je 1993. u Amanu (Jordan)

8. Simpozij o arabizaciji termina održan je 1999. u Damasku (Sirija). ${ }^{25}$

Vjerovatno najzaslužniji za tvorbu novih termina u arapskom jeziku jesu univerzitetski profesori, a posebno oni na Sirijskom univerzitetu (današnji Univerzitet u Damasku), odnosno na Medicinskom fakultetu tog univerziteta na kojem se medicina izučava na arapskom jeziku skoro čitav vijek. Rezultati koje je postigao Univerzitet u Damasku jasno ukazuju da arapski jezik ima kapaciteta da ide u korak sa razvojem terminologije na svjetskom nivou. Njega su slijedile druge obrazovne i naučno-istraživačke institucije u Siriji i kasnije u čitavom arapskom svijetu.

\footnotetext{
${ }^{25}$ Više o odlukama koje su donesene na spomenutim simpozijumima: Muhammed 'Ali Zarkan, El-Džuhud el-lugavijje fil-mustalah el-ilmijj el-hadis, str. 415-423.
} 
Arhisis smatra da se terminologija, kao zasebna lingvistička disciplina kod Arapa, još nije u cijelosti konstituisala, iako se na tom planu ulaže značajan trud još od 1970. godine. ${ }^{26}$ On smatra da se ozbiljnije i konkretnije bavljenje Arapa terminologijom i pokušaji uspostavljanja arapske nauke o terminima javlja u drugoj polovici XX vijeka, jačanjem aktivnosti akademija za arapski jezik, ali i pojavom Koordinacionog biroa za arabizaciju u Rabatu.

Arapi su, bez sumnje, u značajnoj mjeri uspjeli razviti terminologiju na arapskom jeziku. Međutim, kako smatra Abdus-Selam Arhisis, i pored svih napora i rezultata, terminologija se $\mathrm{u}$ arapskom svetu nije profilisala kao zasebna lingvistička disciplina. ${ }^{27}$

$\mathrm{Na}$ kraju možemo konstatovati da se većina autora slaže oko toga da je današnja sveukupna lingvistička arabistika u arapskom svijetu u sjenci one nekadašnje, a da su terminološka istraživanja, uglavnom, koncentrisana na pronalaženje adekvatnih terminoloških rješenja za strane riječi.

\section{Problemi tvorbe i ujedinjavanja terminologije u arapskom svijetu}

Iako se Arapi diče i ponose leksičkim bogatstvom arapskog jezika, neophodno je priznati da se danas arapski jezik susreće sa velikim problemima i izazovima, a to se posebno ogleda na polju terminologije. Tih problema je mnogo, a mi ćemo ukazati na neke od njih.

a) Arapski svijet je četiri vijeka bio pod nearapskom upravom, gdje jezik uprave i jezik javnog života nije bio književni arapski jezik, nego kolokvijalni ili jezik stranih upravitelja.

b) Brzina razvoja nauka i pojmova, odnosno termina vezanih za njih, otežava napore arapskih lingvista da sustignu nivo razvijenih jezika $\mathrm{u}$ svijetu.

\footnotetext{
26 'Arhisis, 'Abdus-Selam, „Iškalat te’sis 'ilmul-mustalahat fis-sekafe el-'arabijje elmu'asire“, Al-Lisan al-'arabijj, Rabat, broj 46, Mekteb et-ta'rib, 1998., str. 1.

27 Ibid.
} 
c) Dugogodišnje razilaženje lingvističkih konzervativaca i modernista oko načina bogaćenja leksike arapskog jezika ostavilo je dubok negativan trag na polje izučavanja i stvaranja termina u arapskom jeziku.

d) Problemi vezani za prirodu samog arapskog jezika, poput polisemije i sinonimije $u$ arapskom jeziku su otežali tvorbu novih termina.

e) Jedna od prepreka je i brojnost jezika izvora iz kojih se terminologija crpi, jer se pojedini pojmovno-terminološki sadržaji preuzimaju iz engleskog i francuskog jezika i za te iste pojmove koriste se različiti termini (na primjer u engleskom se koristi termin „nitrogen“, a u francuskom „azot"), a to se odrazilo i na arapski jezik, pa tako imamo dva termina za jedan pojam: Azut i nitrudžin.

f) Međusobna neusaglašenost $u$ radu institucija ili lica koja se brinu o terminologiji dovodi do postojanja više terminoloških likova za isti pojam.

g) Postoji značajan broj problema na polju obrazovanja, a najznačajniji su nedovoljno i neadekvatno obučen kadar za predavanje arapskog jezika, problemi sa udžbenicima, kao i jezik nastave koji često nije arapski. U Ujedinjenim Arapskim Emiratima postoje 22 univerziteta, a samo na jednom od njih se nastava izvodi isključivo na arapskom jeziku.

Kritički odnos spram razvoja terminologije u arapskom jeziku ima i Arhisis koji smatra da terminologija u arapskoj kulturi neće doživjeti veći uspjeh ili procvat bez „kritičkog osvrta na iskustvo Zapada na ovom polju, a nikako putem 'doslovnog kloniranja zapadnjačkog iskustva'." $\mathrm{Na}$ tom planu, kako dalje navodi Arhisis, istraživač se susreće sa nekoliko teoretskih i praktičnih prepreka.

a) Pri određivanju zadataka vezanih za stvaranje terminologije, potrebno je jasno razgraničiti produkovanje od reprodukovanja znanja.

b) Jasno definisati primijenjene metodologije.

c) Intenzivirati institucionalno bavljenje terminologijom. ${ }^{28}$

${ }^{28}$ Ibid. 
Pored spomenutih, mnoštvo je drugih prepreka sa kojima se arapski lingvisti susreću na polju tvorbe novih termina, a neke od njih su:

1. miješanje/preklapanje termina sa terminima koji se koriste u drugim oblastima,

2. neobičnost značenja termina kada se prenesu iz nekog jezika u arapski jezik,

3. neuvažavanje specifičnosti jezika iz kojeg se termin preuzima,

Zapad institucionalno pristupa terminologiji, dok je terminologija kod Arapa donedavno bila svedena na nivo zalaganja pojedinca, čiji je učinak ograničen. Upravo zbog toga neophodna je podrška vlasti, akademija za arapski jezik, naučno-obrazovna institucija, kao i stručnjak za leksikografiju i terminologiju kako bi se dostigao nivo koji priliči naciji od nekoliko stotina miliona pripadnika. Kod većine jezika terminologija je na teoretskom i praktičnom planu napravila velike i značajne korake, dok u arapskom jeziku još uvijek nije postigla željeni nivo.

M. Hidžazi smatra da je upotreba književnog arapskog jezika danas ograničena na neke oblike književnog stvaralaštva, islamsku tradiciju i historijske nauke, a da bi on, zapravo, morao biti u potpunosti moderan jezik sposoban da prati naučni i tehnološki razvoj u svijetu. ${ }^{29}$

Željeni cilj svih poduzetih mjera i aktivnosti na polju terminologije $u$ arapskom, a i u svakom drugom jeziku, jeste postojanje jednog termina za jedan pojam u okviru jedne oblasti, a sve to kako bi se izbjeglo „terminološko šarenilo“ koje je vladalo u različitim terminosistemima u arapskom jeziku.

\section{Institucije koje se bave terminologijom u arapskom jeziku}

Brz razvoj nauke i tehnologije u svijetu natjerao je čovječanstvo da poduzme odgovarajuće korake na institucijalnom nivou radi promptnog rješavanja problema terminologije. $\mathrm{Na}$ tom planu, kao što smo to

\footnotetext{
${ }^{29}$ Devr el-mustalahat el-muvahhade fi ta'rib el-'ulum ve nešri el-ma'rife“, Al-Lisan al'arabijj, str. 2.
} 
prethodno spomenuli, osnovane su dvije institucije; jedna je Infoterm Centar za terminološke podatke sa sjedištem u Beču i ISO Internacionalna organizacija za standardizaciju. Infoterm, međunarodni informacioni centar za terminologiju, osnovan je 1971, po ugovoru sa UN-ovom organizacijom za obrazovanje, nauku i kulturu (UNESCO), a sa ciljem da podrži i koordinira međunarodnu saradnju iz oblasti terminologije. Zadaća ovih institucija je, dakle, podrška i koordinacija medunarodne saradnje u oblasti terminologije.

Ugledajući se na njih, Arapi su, konačno, shvatili značaj postojanja sličnih institucija koje bi unaprijedile arapsku nauku o terminima i arapsku terminološku praksu, pa su na tom planu poduzeli nekoliko konkretnih koraka. Kao rezultat toga danas postoji nekoliko institucija koje se bave terminologijom u arapskom jeziku. Pomenut ćemo neke od njih.

\section{Akademija za arapski jezik u Damasku ${ }^{30}$}

Akademija za arapski jezik u Damasku utemeljena je 1919. godine, najstarija je akademija za arapski jezik i najstarija institucija koja se bavi arabizacijom državnog sektora, a posebno arabizacijom obrazovanja i obrazovnih institucija. Među brojnim stalnim komisijama pri Akademiji postoji i Komisija za terminologiju. Osnivanje Akademije bilo je odgovor na dominaciju osmanskog turskog jezika u administraciji tokom perioda koji je prethodio njenom osnivanju. ${ }^{31}$

Akademija u Damasku proširila je djelokrug svojih aktivnosti kako bi obuhvatila različite, klasične i moderne, naučne oblasti. Tako je usmjerila svoje snage na stvaranje naučnih stručnih i tehničkih arapskih izraza, koji bi trebalo da nadomjeste upotrebu stranih riječi iz navedenih oblasti. Pored toga, uložila je, a i danas ulaže, dosta velike napore u kritici novinskog jezika različitih informativnih medija, kao i u njegovo čišćenje od vulgarizama. Osim toga, ona održava i stalne kontakte sa drugim akademijama, posebno arapskim, u cilju ujedinjavanja napora i

\footnotetext{
${ }^{30}$ Više o njoj vidi: http://www.arabacademy.gov.sy/index.aspx.

31 Hafizović, Mesud, Lingvističko djelo Ibrahima Enisa, Fakultet islamskih nauka, Sarajevo, 1994., str. 16.
} 
koordinaciji djelovanja u oblasti stvaranja nove naučne i tehničke terminologije. ${ }^{32}$

\section{Akademija za arapski jezik u Kairu ${ }^{33}$}

Akademija za arapski jezik u Kairu utemeljena je 1932. godine, ali je zvanično počela sa radom dvije godine kasnije. Iako je u odnosu na onu iz Damaska nastala kasnije, svojim aktivnostima i značajem postala je najutjecajnija institucija za arapski jezik. Ova Akademija dala je ogroman doprinos razvoju terminologije kod Arapa, kao i arabizaciji uopće. Muhamed Ali al-Zerkan smatra da je Akademija za arapski jezik u Kairu jedina akademija koja se posvetila jeziku i terminologiji, a zatim navodi da su neki istraživači za nju kazali da je „skoro svoje cjelokupno vrijeme posvetila terminologiji“. ${ }^{34}$ Ahmed Šefik al-Hatib napominje da je Akademija za arapski jezik u Kairu za četvrtinu vijeka obogatila arapski jezik i u njega uvrstila više od dvadeset hiljada termina iz različitih naučnih i tehničkih grana. ${ }^{35}$

Ciljevi ove Akademije su: izrada jezičkih rječnika, jezička istraživanja, stvaranje naučnih termina, valorizacija arapskog nasljeđa i različite kulturološke aktivnosti. ${ }^{36}$

3. Iračka naučna akademija u Bagdadu ${ }^{37}$

32 Smajlović, Ahmed, „Od Halila ibn Ahmeda do dr. Teufika Muftića“, Preporod, br. 7 i 8, Sarajevo, 1975., str. 7.

${ }^{33}$ Više o njoj vidi: http://www.sis.gov.eg/VR/acadmy/html/acadmay01.htm.

34 Zarkan, Muhammed 'Ali, „Al-Džuhud el-lugavijje fil-mustalah el-'ilmijj el-hadis“, $A l$ Lisan al-'arabijj, Rabat, broj 44, Mekteb et-ta'rib, 1997., str. 7.

${ }^{35}$ Hatib (al-), Ahmed Šefik, Mu'džem el-mustalahat el-ilmijje vel-fennijje vel-hendesijje: 'Indžlizijj-'Arabijj, Mektebe Lubnan, Bejrut, 1985., str. 749.

${ }^{36}$ Pored ove dvije akademije, postoji još nekoliko akademija za arapski jezik u drugim arapskim zemljama, ali su ove dvije najpoznatije.

37 Više o ovome vidi na oficijelnoj web-stranici Akademije: http://iraqacademy.iq/PageViewer.aspx?id=1 
Iračka naučna akademija sa sjedištem u Bagdadu utemeljena je 1947. godine od strane iračke vlade. Ona iza sebe ima zavidan nivo i broj radova na polju terminologije, a svoje rezultate objavljuje u vlastitom glasilu Časopisu iračke naučne akademije (Medželle al-medžme'a al-ilmijj alirakijj).

Jedan od ciljeva osnivanja Iračke akademije jeste i briga o čistoći arapskog jezika i poduzimanje mjera koje će osigurati da odgovori na zahtjeve koje postavljaju nauka, umjetnost i savremene životne prilike. Pored spomenutog, Akademija se bavi i sakupljanjem naučnih i književnih djela, te umnožavanjem arapskih rukopisa.

4. Koordinacioni biro za arabizaciju u Rabatu ${ }^{38}$

Koordinacioni biro za arabizaciju sa sjedištem u Rabatu osnovan je 1961. godine, a počeo sa radom 1962. godine. U samom početku Biro je bio dio Generalnog sekretarijata Arapske lige, da bi osnivanjem Arapske organizacije za odgoj, kulturu i nauku (ALECSO - El-Munazame el'arabijje lit-terbije ves-sekafe vel-'ulum) 1972. godine postao dio nje.

Glavni zadatak ovog specijaliziranog tijela jeste koordinacija arabizacije savremenih termina na prostoru svih arapskih zemalja, aktivno učešće u iznalaženju najadekvatnijih metoda za korištenje književnog arapskog jezika u javnome životu, na svim nivoima: kulturološkom, naučnom i medijskom nivou, kao i praćenje svih aktivnosti vezanih za arabizaciju na svim naučnim i tehnološkim poljima. Dakle, njegova uloga je da objedini terminološke aktivnosti u arapskom svijetu i da stvorene terminosisteme nametne svim obrazovnim institucijama, s ciljem eliminiranja dvoznačnosti/višeznačnosti termina, koja u velikoj mjeri otežava komunikaciju.

Upravo zbog toga, Biro je sačinio Banku standardizovanih termina (Bank el-mustalahat el-muvahhade) gdje se putem web-pretrage za svaki strani termin može naći odgovarajući termin na arapskome jeziku. Termini su klasificirani u velikom broju specijaliziranih rječnika i ponuđeni na

${ }^{38}$ Više o njemu vidi: www.arabization.org.ma. 
zvaničnoj web-stranici, što uveliko olakšava njihovo korištenje. ${ }^{39}$ Samo do 1986. godine ovaj Biro je standardizovao 67.061 termin i izdao preko trideset specijaliziranih terminoloških rječnika. ${ }^{40}$

Jedan od konkretnih koraka koje je Biro poduzeo jeste izdavanje časopisa specijalizovanog za terminologiju koji nosi ime Al-Lisan al-arabi. Časopis uspješno izlazi već dugi niz godina i sadrži značajne radove vezane za terminologiju u arapskom svijetu i šire, također, sadrži i bilingvalne/višelingvalne terminološke rječnike iz različitih nauka.

5. Udruženje za arapsku leksikografiju u Tunisu. Ovo udruženje postoji i djeluje na državnom nivou i bavi se leksikografskim i terminološkim istraživanjima. $\mathrm{Na}$ tom planu organiziralo je nekoliko međunarodnih simpozija (1993. i 2006), a redovno izdaje časopis Leksikografski Časopis (Medželle al-mu'džemijje).

6. Marokansko udruženje za leksikografska istraživanja vrlo je aktivno na polju leksikološkog i terminološkog istraživanja. ${ }^{41}$

\section{Dosadašnji rezultati na polju arabizacije naučnih oblasti}

Arabizacija različitih nauka i društvenih sektora je arapski nacionalni interes, kako bi se različite nauke i tehnologije približile milionima Arapa i kako bi arapski jezik ostao jezik nauke i arapskog jedinstva.

To iziskuje mnogo napora na različitim poljima, a kako stvari stoje na polju terminologije po različitim oblastima pokazat ćemo sa nekoliko primjera.

1) Prirodne nauke (hemija, fizika, biologija) - termini su unifikovani na samom početku rada Koordinacionog biroa za arabizaciju iz Rabata, a

\footnotetext{
${ }^{39}$ Više o zadacima Biroa može se naći na: http://www.arabization.org.ma/Objectifs.aspx. ${ }^{40}$ Hamzavi (al-), Muhammed Rešad, Al-Menhedžijje al-'amme li tardžemetil-mustalahat ve tevhidiha ve tanmitiha, Dar al-garb al-'islamijj, Bejrut, 1986., str. 14.

41 'Ilm al-istilah ve sina'atul-mustalah, str. 11.
} 
postavljena su teoretsko-metodološka pravila za stvaranje novih termina za svaku od ovih disciplina.

2) Medicinske nauke - na ovom planu od 1811. godine, otkako se u arapskom svijetu izučava medicina na akademskom nivou, načinjeni su značajni iskoraci, a poseban doprinos pripisuje se akademijama za arapski jezik, odnosno Medicinskom fakultetu Univerziteta u Damasku.

3) Industrija - postoji veliko terminološko šarenilo u ovoj oblasti, s obzirom na to da svaka grana i skupina (istraživači, učesnici u procesu proizvodnje, distributeri...) koriste vlastite termine.

4) Ekonomija i finansije - postoje osnovni termini za ovu oblast.

5) Društvene nauke - terminosistemi u ovoj oblasti relativno su novi, ali ih je potrebno usaglasiti.

6) Politika i upravljačke strukture - skoro svi termini ove skupine su unifikovani. ${ }^{42}$

Iz prethodno iznesenog se dâ zaključiti da stanje u pogledu različite stručne terminologije nije zadovoljavajuće. Isto tako, na tom polju daju se zapaziti određeni napredak i napori u pravcu rješavanja problema, posebno u pravcu izrade specijaliziranih terminoloških rječnika u okrilju Biroa u Rabatu. ${ }^{43}$

\section{Preporuke za unapređenje nauke o terminima u arapskom jeziku}

Nakon što smo predstavili značaj istraživanja terminoloških pitanja, bitno je istaći nekoliko konkretnih preporuka za unapređenje nauke o terminima $\mathrm{u}$ arapskom jeziku.

- Neophodno je nastaviti osnovna teorijska i praktična istraživanja na polju terminoloških problema u arapskom jeziku na svim poljima, jer ona predstavljaju glavni preduslov za napredak nauke i bolju naučnu

\footnotetext{
42 Devr al-mustalahat al-muvahhade fi ta'rib al-'ulum ve nešril-ma'rife“, Al-Lisan al'arabijj, str. 5-7.

43 http://www.arabization.org.ma/Standarddesdictionnaires.aspx.
} 
komunikaciju; to se može realizovati putem osnivanja posebnih tijela za terminološka istraživanja na univerzitetima širom arapskog svijeta, kao što se to radi na nekim univerzitetima u Evropi.

- Neophodno je, bez ikakvog ograničavanja na uske specijalizovane krugove, koristiti savremena tehnološka pomagala i sredstva informisanja, poput savremenih tehnoloških dostignuća iz polja informatike i internet-mreže, kako bi se pristup terminologiji na arapskom jeziku učinio dostupnim širim masama. ${ }^{44}$

- Posebnu pažnju treba posvetiti mjestu terminologije u obrazovnom procesu, na svim nivoima. To iziskuje preispitivanje planova i programa obrazovnih institucija u svim arapskim zemljama kako bi sutrašnje generacije bile pošteđene loših iskustava na polju korištenja terminoloških izraza.

- Vrlo važnu ulogu u stvaranju pojedinih terminosistema imaju prevodioci stručne literature sa stranih jezika, jer je upravo prevodilački proces bio jedan od značajnih razloga postojanja i širenja višeznačnosti termina $\mathrm{u}$ arapskom jeziku.

- Potrebno je uvesti zanimanje „terminolog“ (ar. mustalehijj). Takav stručnjak bi se posvetio davanju mišljenja vezanih za termine, ali i izradi monolingvalnih ili bilingvalnih terminoloških rječnika.

- Neophodna je i zakonska legislativa koja će uticati na to da specijalizirana državna tijela povedu veću brigu o stvaranju terminologije $\mathrm{u}$ arapskom jeziku.

- Značajno mjesto u aktivnostima vezanim za izradu terminologije zauzimaju mediji, zbog svog velikog uticaja na cjelokupno stanovništvo. ${ }^{45}$

\footnotetext{
44 Ova tačka je primijenjena na primjeru web-stranice Biroa za arabizaciju: www.arabization.org.ma.

45 „Devr al-mustalehat al-muvahhade fi ta'ribil-'ulum ve nešril-ma'rife“, Al-Lisan al'arebijj, str. 8-9.
} 
- Dodatni angažman na polju svearapskog jedinstva, što će pridonijeti ukupnom jačanju arapskog jezika, a samim tim i terminologije $u$ arapskom jeziku.

\section{Literatura}

a) Knjige

1. 'Arhisis, 'Abdus-Selam, „Iškalat te'sis 'ilmul-mustalahat fis-sekafe al'arabijje al-mu'asire“, Al-Lisan al-'arabijj, Rabat, broj 46, Mekteb alta'rib, 1998.

2. Džahiz (al-), 'Amr, Al-Bejan vet-tebjin, Dar al-Handži, Kairo, 1998.

3. Džahiz (al-), 'Amr, Al-Hajevan, Maktebe Mustafa al-Babi, Kairo, 1965.

4. Hafizović, Mesud, Lingvističko djelo Ibrahima Enisa, Fakultet islamskih nauka, Sarajevo, 1994.

5. Hamzavi (al-), Muhammed Rešad, Al-Menhedžijje al-'amme li tardžemetil-mustalahat ve tevhidiha ve tanmitiha, Dar al-garb al'islamijj, Bejrut, 1986.

6. Hatib (al-), Ahmed Šefik, Mu'džem al-mustalahat al-'ilmijje ve alfennijje ve al-hendesijje: 'Indžlizijj-'Arabijj, Mektebe Lubnan, Bejrut, 1985.

7. Kasimijj (al-), 'Ali, 'Ilmul-istilah ve sina'atul-mustalah, Mektebe Lubnan, 2008.

8. Kico, Mehmed, Arapska jezikoslovna znanost, Sarajevo, 2003.

9. Kinvan, el-Husejn, „Ed-Dirase el-mustalahijje mefhumen ve menhedžen", Nedve ed-dirase el-mustalehijje ve el-ulum al-'islamijje, Matba'a el-me'arif el-džedide, Rabat, 1996.

10. Muftić, Teufik, Arapsko-bosanski rječnik, El-Kalem, Sarajevo, 2004.

11. Muftić, Teufik, Gramatika arapskog jezika, Ljiljan, Sarajevo, 1998.

12. Sama'ane, Dževad Husni, „Menhedžijetul-vad'i el-mustalah el-'arabijj ve tedžellijatuha fi el-mu'džem el-mutehassis", Nedve ed-dirase almustalahijje ve al-'ulum al-'islamijje, Matba'a el-me'ariful-džedide, Rabat, 1996.

13. Sinani, Sinani, Al-Tetavvur al-dilalijj li al-mustalah al-fikbijj, Medžma‘ al-luga al-'arabijje, Damask, br. 85, tom' 3, 2010. 
14. Smajlović, Ahmed, „Od Halila ibn Ahmeda do dr. Teufika Muftića“, Preporod, br. 7 i 8, Sarajevo, 1975.

15. Ubbezijj (al-), Šihabuddin, Bejan kašfil-'elfaz, Maktaba al-Handžijj, 2002.

16. Zabidi (al-), Murteda, Tadžul-'arus, Vizaretul-'iršad ve al-'enba', Kuvajt, 1969.

17. Zafnaki, Safijja, Al-Menahidž al-mustalahijje, Al-Hej'e al-'amme assurijje lil-kitab, 2010.

18. Zarkan, Muhammed 'Ali, „Al-Džuhud al-lugavijje fi al-mustalah al'ilmijj al-hadis“, Al-Lisan al-'arabijj, Rabat, broj 44, Mekteb al-ta'rib, 1997.

b) web:

19. Mattad (al-), 'Abdul-'Aziz, „Al-'Usulul-'arabijje el-islamijje li 'ilmilmustalah", Medželletul-aklam es-sekafijje, http://www.aklaam.net/newaqlam/aqlam/show.php?id=10691

20. http://www.arabization.org.ma/Standarddesdictionnaires.aspx.

21. http://www.arabization.org.ma/Objectifs.aspx.

22. www.arabization.org.ma.

23. http://iraqacademy.iq/PageViewer.aspx?id=1

24. http://www.sis.gov.eg/VR/acadmy/html/acadmay01.htm.

25. http://www.arabacademy.gov.sy/index.aspx. 
Hajrudin Hodzic, $\mathrm{PhD}^{46}$

\section{STUDY OF TERMINOLOGY IN ARABIC LANGUAGE}

\section{Abstract}

Terms are necessary tools and means of precise understanding, and their importance is especially pointed out in the professional and scientific fields, where there is no place for vagueness, imprecision and ambiguity. Harmonized and integrated terminology represents an even greater driving force that gives power to any language to cope with the challenges that humanity faces today. Therefore, the continuous development of the terminology is the most important prerequisite for the development of any language, particularly the most widespread languages like Arabic.

This work, first of all, explains the chronological development of terminology as a science in the Arabic language, and then lists the most important individuals and institutions that have been engaged in this subject in the Arab world. Important part of this paper is to shed light on the situation in the field of Arabization of scientific fields, due to the fact that Arabization represents an important prerequisite for monitoring of all types of development in the world, but also for the modernization of the Arabic language.

Keywords: terminology, dates, Mustalah, Academy for the Arabic language, Arabization

46 The Islamic Pedagogical Faculty in Bihac. 
الدكتور خير الدين هوجيتش

\section{دراسة المصطلحات في اللغة العربية}

\section{خلاصة}

المصطلحات آلة ووسيلة ضرورية لفهم سديد، وتتأكد أهميتها في مجالات علمية

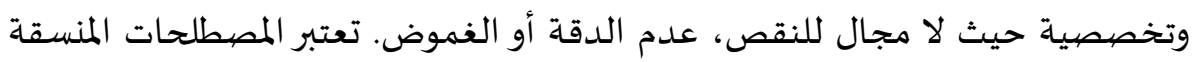

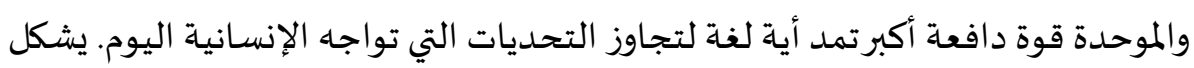

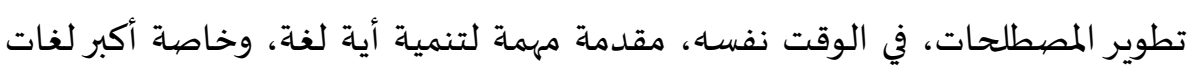
العالم كما هو الحال بالعربية.

يوضح هذا البحث، قبل كل شيء، تطوير المصطلحات التاريخي في اللغة العربية،

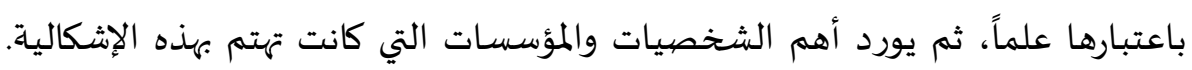
الجزء الذي لا يتجزئ من هذا البحث هو تسليط الضوء على تعريب المجالات العلمياة،

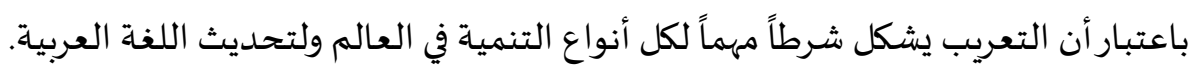

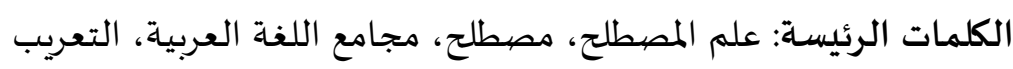

